\title{
Perencanaan Pengelolaan Wisata Pedesaan di Desa Bumiaji, Kota Batu, Kabupaten Malang, Jawa Timur
}

\author{
Rucitarahma Ristiawan \\ Program Studi Pariwisata, Fakultas Ilmu Budaya, Universitas Gadjah Mada \\ Posel: rucitarahma@ugm.ac.id \\ Tim Pengabdian Masyarakat \\ Tular Sudarmadi, Fahmi Prihantoro, Wiwik Sushartami, Yulita Kusuma Sari
}

\begin{abstract}
Administratively, Bumiaji Village is located in Bumiaji District, Batu City, Malang Regency, East Java. Since 2016, the Bumiaji Village Government has prioritized the development of the tourism sector as one of the productive economic priority sectors. It is based on a decline in apple and citrus agricultural output due to a decrease in soil quality and an increase in global temperatures that have an impact on the quality of apple and orange products. With the allocation of more village funds than any other village in Batu City, tourism development in Bumiaji Village is carried out through a variety of development programs, ranging from village, sub-district and district governments. The development programs overlap and are not integrated with each other. In addition, the emergence of several tourism service businesses and the management of individual tourist attractions in the village of Bumiaji have an impact on the uneven distribution of income obtained through tourism development. Using a network of cooperation with the Malang Regency government, the District Government, and the manager of the Pujon Tourism Village, the FIB UGM Tourism Study Program conducted workshops and mentoring in discussions on the formation of an integrative institution management of village tourism. This article describes the efforts that can be taken by the village government in managing, assisting and developing tourism in Bumiaji Village. In detail, this article describes the efforts to systematize village tourism institutions that can be carried out by village governments. Through the institutional systematization in the management of rural tourism, tourism development that will be carried out in the future will be integrated and have a positive and direct impact evenly for the local community.
\end{abstract}

Keywords: community service, tourism management institutions, village tourism, tourism development

\begin{abstract}
Abstrak
Secara administratif, Desa Bumiaji terletak di Kecamatan Bumiaji, Kota Batu Kabupaten Malang, Jawa Timur. Sejak 2016, Pemerintah Desa Bumiaji memprioritaskan pembangunan sektor pariwisata sebagai salah satu sektor prioritas ekonomi produktif. Hal ini dilandasi oleh adanya penurunan hasil pertanian apel dan jeruk akibat penurunan kualitas tanah serta kenaikan suhu global yang berdampak pada kualitas produk apel dan jeruk. Dengan alokasi dana desa yang lebih banyak daripada desa lain di Kota Batu, pembangunan pariwisata di Desa Bumiaji dilakukan melalui beragam program pembangunan, mulai dari pemerintah tingkat desa, kecamatan, hingga kabupaten. Program-program pembangunan tersebut menjadi tumpang tindih dan tidak terintegrasi satu sama lain. Selain itu, munculnya beberapa usaha jasa kepariwisataan dan
\end{abstract}


pengelolaan atraksi wisata secara perorangan di Desa Bumiaji berdampak pada tidak meratanya pembagian hasil yang didapatkan melalui pembangunan pariwisata. Menggunakan jejaring kerja sama dengan pemerintah Kabupaten Malang, Pemerintah Kecamatan, dan pengelola Desa Wisata Pujon, Prodi Pariwisata FIB UGM melakukan kegiatan workshop dan pendampingan dalam diskusi pembentukan kelembagaan yang integratif dalam pengelolaan pariwisata desa. Artikel ini menjelaskan upaya yang dapat ditempuh oleh pemerintah desa dalam melakukan pengelolaan, pendampingan, dan pengembangan kepariwisataan di Desa Bumiaji. Secara rinci, artikel ini menjelaskan upaya-upaya sistematisasi kelembagaan pariwisata desa yang dapat dilakukan oleh pemerintah desa. Harapannya, dengan adanya sistematisasi kelembagaan dalam pengelolaan pariwisata desa, pembangunan pariwisata yang akan dilakukan mendatang menjadi terintegrasi dan berdampak positif secara langsung serta merata bagi masyarakat lokal.

Kata Kunci: pengabdian masyarakat, kelembagaan pengelolaan pariwisata, wisata desa, pembangunan pariwisata

\section{Pendahuluan}

Kelembagaan dalam pengelolaan pariwisata menjadi aspek dasar bagi upaya pembangunan pariwisata, utamanya di wilayah pedesaan (Lane, 1994). Beberapa ahli juga mengatakan bahwa kelembagaan yang sistematis dan efisien dalam pengelolaan pariwisata desa berbasis masyarakat berfungsi sebagai salah satu faktor kunci dalam keberhasilan pengelolaan pariwisata pedesaan, seperti pengelolaan pariwisata pedesaan di Cyprus (Sharpley, 2002), Kenya (Manyara dan Jones, 2007), Amerika Selatan (Gascon, 2013), dan Tanzania (Salazar, 2012). Selain itu, dalam aspek pembangunan modal sosial masyarakat desa, kelembagaan pengelolaan pariwisata desa yang beranggotakan masyarakat lokal meningkatkan kerja sama masyarakat lokal dalam pembangunan pariwisata di wilayah mereka sebagai salah satu sektor ekonomi produktif (Zhao, Ritchie, dan Echtner, 2011).

Pentingnya pengelolaan pariwisata pedesaan melalui kelembagaan yang beranggotakan masyarakat lokal menjadi landasan dari adanya inisiasi pembentukan kelembagaan dalam pengelolaan pariwisata pedesaan di Desa Bumiaji. Desa Bumiaji terletak di Kecamatan Bumiaji, Kota Batu yang berada sejauh 3 km sebelah utara AlunAlun Kota Batu dan di sebelah selatan Selecta. Desa Bumiaji terletak di ketinggian 1.200 mdpl dan bersuhu $18-28^{\circ} \mathrm{C}$ setiap tahunnya. Sebagai desa yang mayoritas penduduknya bekerja sebagai petani buah, kondisi perekonomian dari aktivitas produksi pertanian tersebut sangat bergantung pada kualitas tanah. Dalam sepuluh tahun terakhir, terjadi penurunan drastis produksi buah-buahan di Desa Bumiaji karena kualitas tanah yang semakin menurun akibat penggunaan pupuk kimia. Kondisi tersebut membuat masyarakat lokal mencari alternatif sumber penghidupan baru. Industri pariwisata dianggap sebagai salah satu alternatif utama mata pencaharian masyarakat lokal walaupun belum ada upaya pembangunan secara integratif yang dilakukan oleh pemerintah lokal Kota Batu Malang.

Sebagai desa yang terletak di antara Alun-Alun Kota Batu-Pusat Kegiatan Wilayah—dan Selecta, Desa Bumiaji memiliki posisi strategis dalam pengembangan pariwisata karena lokasinya berada di jalur utama akses wisata Kota Batu. Posisi strategis tersebut tidak diiringi oleh adanya upaya pengembangan yang berkelanjutan dari pemerintah Kota Batu. Desa Bumiaji belum dapat bersaing dengan atraksi wisata 
minat khusus yang tersebar di Kota Batu. Peluang diferensiasi produk dan peningkatan pendapatan masyarakat lokal serta kemandirian ekonomi masyarakat menjadi isu penting yang menjadi landasan bagi program pengembangan pariwisata di Desa Bumiaji. Selain itu, program-program pembangunan pariwisata yang diinisiasi oleh pemerintah tingkat desa, kecamatan, hingga kabupaten terkesan tumpang tindih dan tidak terintegrasi. Munculnya beberapa usaha jasa pariwisata dan pengelolaan atraksi wisata secara perorangan di Desa Bumiaji berdampak pada tidak meratanya pembagian hasil yang didapatkan melalui pembangunan pariwisata

\section{Kepariwisataan Desa Bumiaji}

Pada dasarnya, masyarakat Desa Bumiaji merupakan masyarakat yang mayoritas bekerja sebagai petani. Masyarakat umumnya memiliki lahan pertanian di wilayah utara Desa Bumiaji yang memiliki ketinggian sekitar 1.300-1.400 mdpl. Komoditas pertanian utama masyarakat Desa Bumiaji adalah apel dan jeruk. Sebelum tahun 2010, apel menjadi komoditas utama pertanian masyarakat Desa Bumiaji, tetapi penggunaan pupuk kimia secara reguler menyebabkan penurunan kualitas tanah. Hal tersebut berakibat pada penurunan kualitas dan kuantitas produksi apel dari tahun ke tahun. Jeruk menjadi alternatif tanaman produksi walaupun secara harga tidak setinggi harga apel.

Penurunan produksi pertanian menyebabkan pemerintah desa bersama beberapa masyarakat yang tergabung dalam gabungan kelompok tani menjadikan pariwisata sebagai alternatif sumber ekonomi produktif di Desa Bumiaji. Melalui inisiatif tersebut, masyarakat lokal mulai difasilitasi oleh pemerintah desa untuk mendapatkan pelatihan dan pendampingan pengembangan atraksi wisata. Pada tahap tersebut, masyarakat telah berhasil mengidentifikasi beberapa potensi wisata yang dimiliki oleh Desa Bumiaji. Selain itu, beberapa anggota masyarakat mulai mengembangkan bisnis petik apel dan petik jeruk sebagai atraksi wisata. Pada 2017, sekelompok masyarakat mulai mengembangkan produk olahan jeruk menjadi "Batu Orange Cake" sebagai oleh-oleh khas Bumiaji.

Pengembangan atraksi pariwisata tersebut dianggap potensial untuk menaikkan pendapatan lokal Desa Bumiaji oleh pemerintah Kecamatan Bumiaji. Melalui alokasi dana desa pada 2017-2019, pembangunan pariwisata menjadi agenda utama pembangunan Desa Bumiaji, yang meliputi pembangunan infrastruktur, atraksi wisata baru, serta program pelatihan dan workshop pengembangan atraksi wisata. Selain program inisiasi dari pemerintah desa, pemerintah Kecamatan Bumiaji juga menjadikan pengembangan pariwisata desa di Desa Bumiaji sebagai prioritas. Alokasi dana yang dikeluarkan oleh pihak Kecamatan Bumiaji sebagian besar digunakan untuk kegiatan promosi melalui pembuatan video promosi, pelatihan, workshop pembangunan agrowisata desa, serta untuk menyewa jasa konsultan dalam pengembangan pariwisata Desa Bumiaji.

\section{Peran Akademisi dalam Pengembangan Kelembagaan Pariwisata Desa di Desa Bumiaji}

Sebagai salah satu upaya untuk memberdayakan warga Desa Bumiaji dalam pengelolaan pariwisata desa, tim pengabdian masyarakat Prodi Pariwisata yang memiliki kompetensi dalam kajian pengelolaan kelembagaan pariwisata berkontribusi dalam sumbangsih 

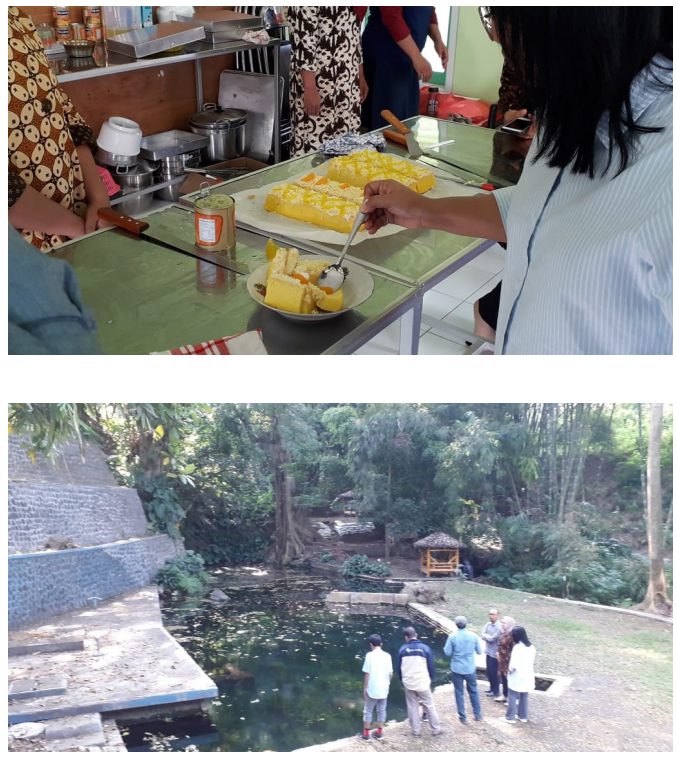

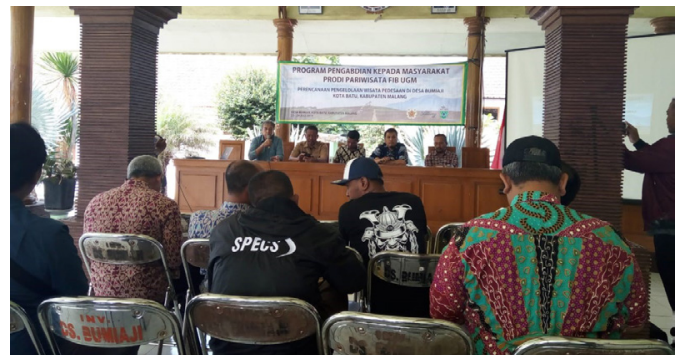

Gambar 1. Kegiatan Pengabdian Masyarakat Prodi Pariwisata Juli 2019. (Sumber: Dokumentasi Tim PKM Desa Bumiaji Prodi Pariwisata 2019)

pemikiran dan ide terkait dengan skema pengelolaan dan kelembagaan pariwisata desa di Desa Bumiaji. Program Pengabdian Masyarakat Program Studi Pariwisata ini bertujuan untuk mengintegrasikan upaya pengelolaan yang sudah ada melalui suatu usulan skema kelembagaan pengelolaan pariwisata desa.

Dalam program ini, tahapan pelaksanaan dibagai menjadi tiga, yaitu tahap jangka pendek, jangka menengah, dan jangka panjang. Masing-masing tahapan akan dilakukan selama satu tahun. Program tahun pertama dilakukan pada Juli 2019 yang berupa sosialisasi dan pendataan kelembagaan terkait dengan pengembangan pariwisata di Desa Bumiaji. Program selanjutnya akan dilaksanakan pada Juli 2020 yang berupa evaluasi kerja kelembagaan serta pengembangan kemitraan. Program ketiga akan dilaksanakan pada Juli 2021 dengan program evaluasi kinerja, kaderisasi anggota pengelola, dan penguatan jejaring kemitraan.

Dalam artikel ini, secara khusus diuraikan program pengabdian masyarakat tahap pertama yang dilakukan oleh Program Studi Pariwisata FIB UGM di Desa Bumiaji. Secara induktif, strategi pengembangan kelembagaan pengelola pariwisata desa dilakukan melalui wawancara dengan perangkat desa untuk mendapatkan data terkait dengan pelaksanaan program-program pengembangan kepariwisata dan isu-isu strategis terkait dengan pengelolaan kepariwisataan di Desa Bumiaji, observasi lapangan untuk mengamati aktivitas pengelolaan yang dilaksanakan secara perorangan di Desa Bumiaji, serta focus group discussion yang diikuti oleh perangkat desa, pemerintah kecamatan Bumiaji, pengelola atraksi wisata perorangan di Desa Bumiaji, dan anggota karang taruna untuk mengkaji isu-isu strategis dan permasalahan pengelolaan kelembagaan. Secara terperinci, tahapan dalam penelitian ini adalah sebagai berikut.

\section{Pengumpulan Data}

Data yang dikumpulkan mencakup data profil wilayah, atraksi wisata, informasi terkait dengan pengelolaan eksisting, dan informasi tentang program-program pembangunan pariwisata yang telah dilakukan. Data tersebut diperoleh melalui sumber primer dengan 
metode observasi yang dilakukan selama 2 hari saat kegiatan pengabdian masyarakat berlangsung guna mendapatkan informasi terkait upaya-upaya pembangunan dan pengelolaan atraksi wisata di Desa Bumiaji. Selain itu, data dari sumber primer juga diperoleh berdasarkan hasil wawancara dengan pihak perangkat desa, yaitu Pelaksana Tugas Kepala Desa Bumiaji, Kepala Urusan Sumber Daya Manusia Desa Bumiaji, Kepala Urusan Keuangan Desa Bumiaji, Pengelola Agrowisata Jambu Kristal, Pengelola Hutan Papringan, dan Kepala Urusan Pengabdian Masyarakat Kecamatan Bumiaji. Data primer yang diperoleh diperkuat dengan data sekunder yang dikumpulkan dari referensi-referensi dari sumber tertulis seperti artikel, buku, dan catatan-catatan tertulis pemerintah Desa Bumiaji tentang sejarah Desa Bumiaji, monografi Desa Bumiaji, dan inventarisasi produk wisata di Desa Bumiaji.

\section{Analisis Data}

Data yang sudah terkumpul dikelompokkan sesuai dengan kategori yang dirumuskan, yaitu data pengelolaan atraksi wisata eksisting, pelaksanaan program-program pembangunan pariwisata di Desa Bumiaji, serta permasalahan dan isu strategis dalam pengelolaan pariwisata desa di Desa Bumiaji. Hasil pengelompokan setiap kategori data akan diinterpretasi dan direlasikan dengan konsep dasar pembentukan kelembagaan dalam pengelolaan pariwisata pedesaan. Proses analisis ini didasarkan pada paradigma pariwisata berkelanjutan, yang salah satu aspeknya adalah pengelolaan pariwisata berbasis masyarakat. Hasil dari proses analisis data menjadi dasar pembuatan rekomendasi skema pengelolaan pariwisata desa yang dapat diadaptasi sebagai model pengelolaan pariwisata desa di Desa Bumiaji.

\section{Aspek Kelembagaan dalam Pengelolaan Pariwisata Desa}

Dalam pengembangan pariwisata desa, lembaga sebagai institusi formal yang beranggotakan masyarakat lokal menjadi salah satu aspek mendasar dalam upaya pembangunan dan pengembangan produk pariwisata pedesaan (Forstner, 2004; Sebele, 2010). Pariwisata berbasis masyarakat sebagai salah satu bentuk pengembangan pariwisata secara berkelanjutan (Suansri, 2003) menitikberatkan keterlibatan masyarakat dalam kelembagaan, mulai dari tahap awal pembentukan, pengembangan, serta evaluasi (RuizBallesteros dan Caceres-Feria, 2016).

Menurut Atorough dan Martin (2012), tantangan utama dalam pengembangan pariwisata dalam konteks pedesaan adalah distribusi manfaat ekonomi yang diperoleh dari aktivitas wisata kepada masyarakat desa. Hal ini dilandasi oleh perbedaan kepentingan dan motivasi pembangunan yang dimiliki oleh masing-masing pemangku kepentingan (Munar, 2011).

Untuk mengatasi permasalahan tersebut, Adeyinka-Ojo, Khoo-Lattimore dan Nair (2014) mengusulkan suatu model manajemen organisasi untuk destinasi wisata pedesaan. Skema tersebut mencakup dua aspek utama, yaitu aspek manajemen destinasi dan manajemen pemasaran. Secara spesifik, manajemen destinasi meliputi beberapa aspek, yaitu pengembangan sumber daya manusia, pengelolaan keuangan, manajemen krisis dan keamanan lingkungan, manajemen kebijakan politik dan strategi destinasi, dan 


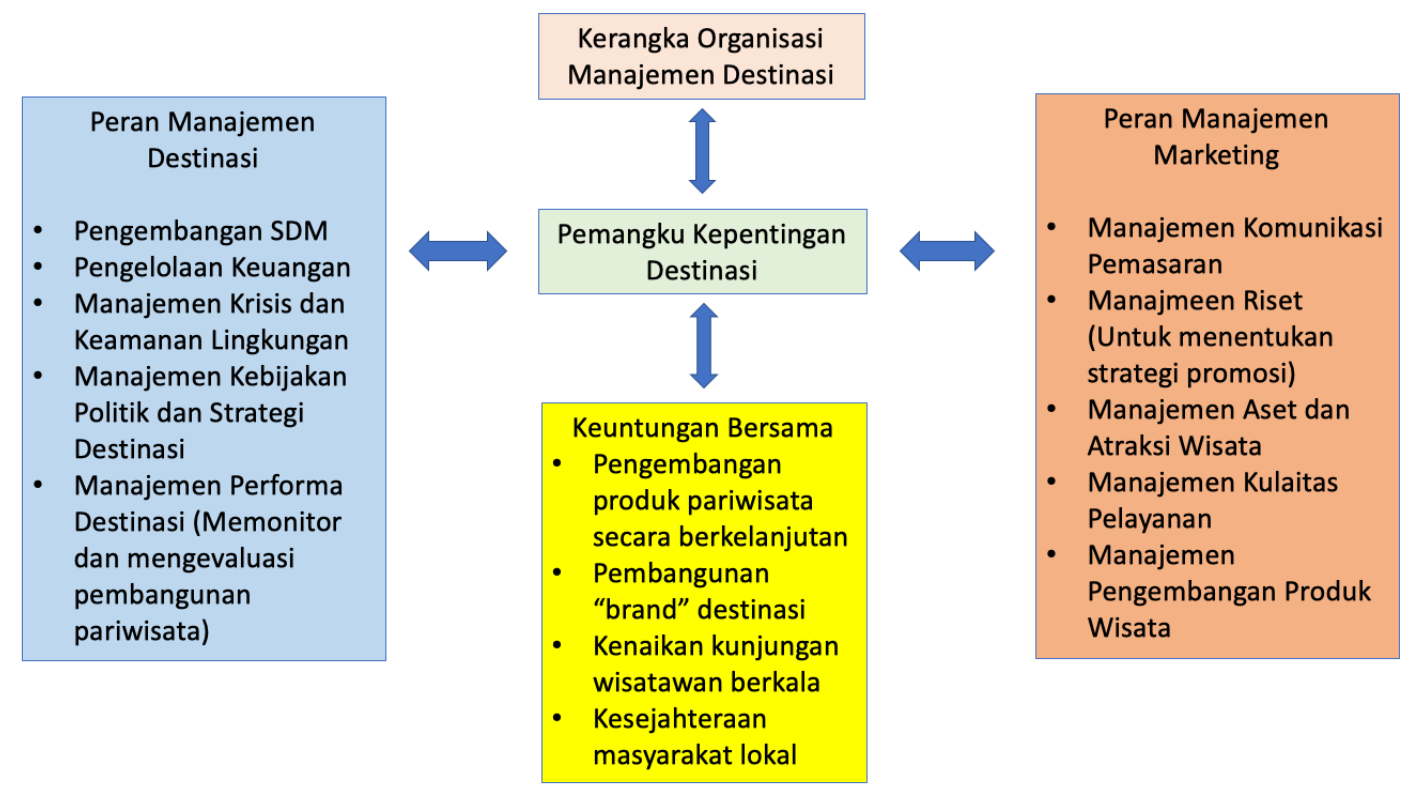

Gambar 2. Kerangka Organisasi Manajemen Destinasi Wisata (Sumber: Diadaptasi dari Adeyinka-Ojo dkk., 2014)

manajemen performa destinasi yang bertugas untuk memonitor dan mengevaluasi kinerja pembangunan pariwisata desa secara menyeluruh. Berbeda dengan manajemen destinasi, manajemen pemasaran dalam model ini lebih berorientasi kepada aktivitas promosi dan pemasaran, seperti manajemen komunikasi pemasaran, manajemen riset untuk menentukan strategi promosi, manajemen aset dan atraksi wisata secara berkelanjutan, manajemen kualitas pelayanan dan pengalaman, serta manajemen pengembangan produk wisata. Gambar 2 menjelaskan secara skematis kerangka manajemen destinasi wisata untuk wilayah pedesaan.

Dalam kerangka tersebut, partisipasi, keterlibatan, dan kolaborasi antara beberapa pemangku kepentingan terkait dengan pengembangan pariwisata menjadi kunci dari kesuksesan upaya pengembangan pariwisata. Kolaborasi, keterlibatan, dan partisipasi antarpemangku kepentingan akan membagi secara merata tugas pembangunan sesuai dengan kapasitas masing-masing (Jamal dan Getz, 1995; Byrd, 2007). Hal tersebut dianggap akan mempercepat proses pembangunan pariwisata karena alokasi sumber daya secara tepat dibagi dan diselesaikan oleh masing-masing pemangku kepentingan sesuai dengan kapasitas dan minatnya.

\section{Gambaran Pengelolaan Pariwisata Desa Eksisting di Desa Bumiaji}

\section{Pengelolaan Atraksi Wisata di Desa Bumiaji}

Secara umum, aktivitas pengembangan pariwisata desa di Desa Bumiaji sudah dimulai sejak tahun 2010. Masyarakat lokal, melalui program workshop dan diskusi intensif dengan pihak Kecamatan Bumiaji, melirik pariwisata sebagai alternatif penghasilan yang disebabkan oleh penurunan produksi pertanian apel. Hal tersebut diperkuat dengan posisi Kota Batu yang menjadi salah satu destinasi wisata unggulan, yang 
masuk dalam lingkup Kawasan Strategis Pariwisata Nasional Bromo, Malang dalam koridor C Pengembangan Pariwisata Provinsi (Pemerintah Kabupaten Malang, 2015). Selain itu, lokasi Desa Bumiaji yang terletak di sebelah utara Alun-Alun Kota BatuPusat Kegiatan Wilayah-dan berada di jalan arteri primer Kota Batu dianggap strategis oleh pemerintah Kecamatan Bumiaji. Hal tersebut menjadi salah satu dasar pemerintah Kecamatan Bumiaji dan masyarakat lokal Desa Bumiaji mulai menggiatkan pengembangan kepariwisataan secara lokal.

Hingga tahun 2019, Desa Bumiaji telah mengembangkan setidaknya 12 atraksi wisata dan 1 produk olahan kuliner lokal sebagai produk wisata. Berdasarkan hasil observasi dan studi dokumen inventaris atraksi wisata di Desa Bumiaji, terdapat beberapa atraksi wisata yang sudah dikelola secara personal ataupun kelompok. Atraksi wisata tersebut, di antaranya, adalah sebagai berikut.

\section{Perkebunan Jambu Kristal}

Perkebunan Jambu Kristal merupakan kebun buah yang dikelola secara personal oleh salah seorang anggota masyarakat. Aktivitas wisata yang dilakukan di lokasi ini utamanya adalah petik jambu. Selain itu, setelah melakukan aktivitas wisata petik jambu, pengunjung dapat menikmati produk olahan jambu kristal seperti keripik jambu dan minuman jambu.
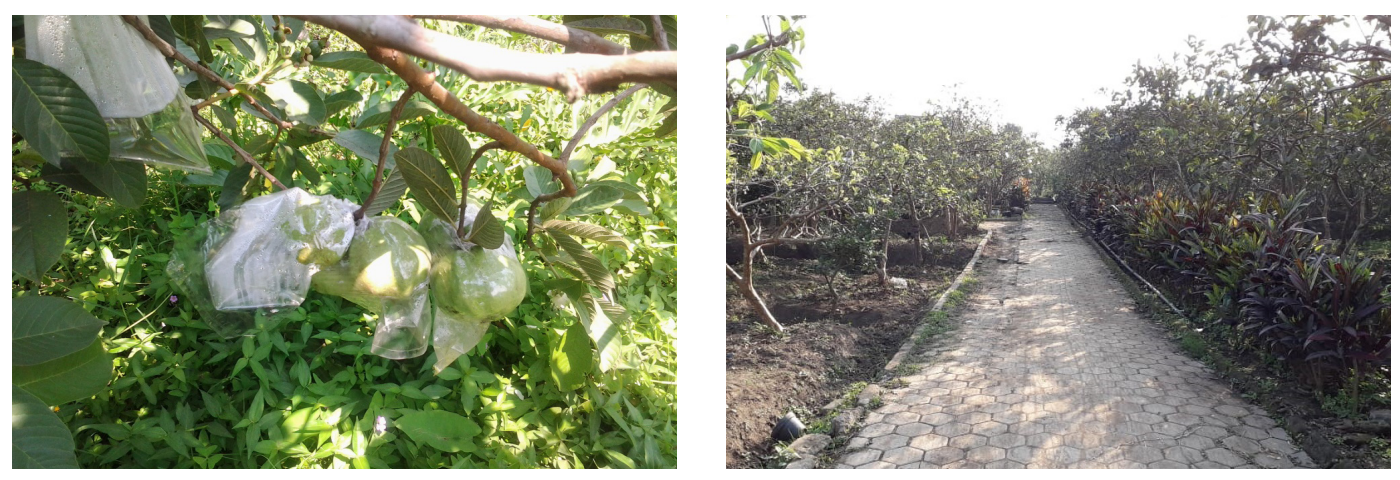

Gambar 3. Perkebunan Jambu Kristal (Tim PKM Desa Bumiaji). (Sumber: Dokumentasi Tim PKM Desa Bumiaji Prodi Pariwisata tahun 2019)

Dalam pelaksanaan pengelolaannya, masyarakat lokal dilibatkan dalam pengurusan hal teknis dan administrasi. Upaya pemberdayaan masyarakat dilakukan oleh pemilik atraksi wisata petik jambu sejak tahap awal pengembangan atraksi wisata. Meskipun dikelola secara personal, pengelola terlibat aktif dalam forum Kelompok Sadar Wisata Desa Bumiaji melalui keterlibatannya dalam berbagai workshop yang diselenggarakan oleh Kelompok Sadar Wisata, pemerintah desa, ataupun pemerintah kecamatan.

\section{Kebun Jeruk dan Apel}

Secara umum, mayoritas perkebunan di Desa Bumiaji merupakan kebun jeruk yang dikelola secara personal oleh masyarakat lokal. Akan tetapi, hanya ada dua kebun yang sudah dimanfaatkan untuk aktivitas wisata. Aktivitas wisata yang umumnya dilakukan adalah wisata petik jeruk. Pengunjung harus melakukan pesanan terlebih dulu karena ketersediaan pohon jeruk yang siap petik harus dihitung dan dipastikan terlebih dahulu jumlahnya oleh pengelola. 

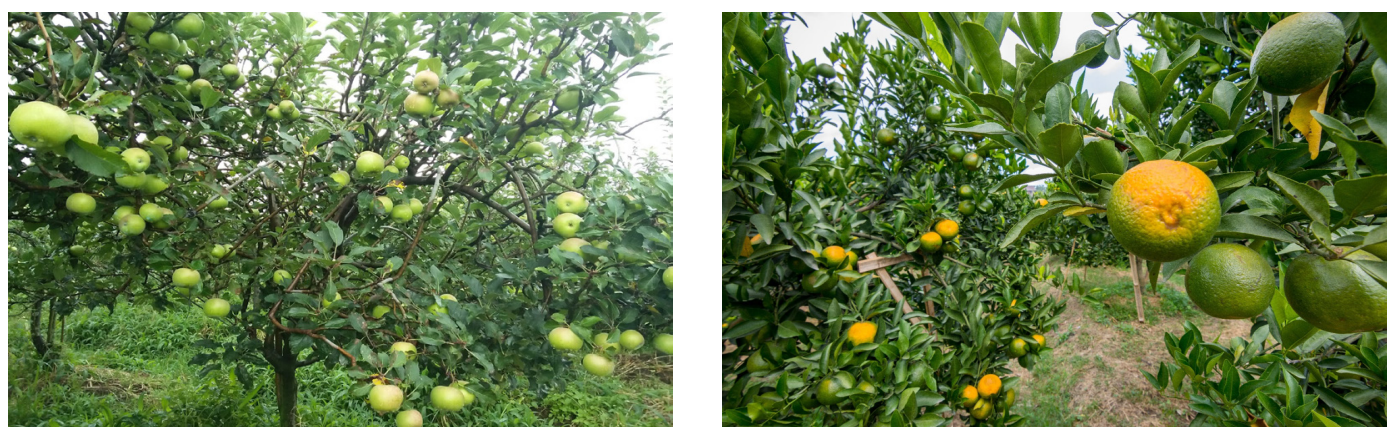

Gambar 4. Kebun Apel dan Jeruk Desa Bumiaji. (Sumber: Dokumentasi Tim PKM Desa Bumiaji Prodi Pariwisata tahun 2019)

Pengelolaan aktivitas wisata di kebun jeruk ini dikelola secara personal oleh warga. Pengelolaan secara mikro ini menyebabkan belum adanya aktivitas promosi yang dilakukan secara sistematis. Biasanya, pengunjung yang datang dibawa oleh agen perjalanan wisata yang sudah memesan paket wisata petik jeruk beberapa minggu sebelum melakukan kunjungan wisata. Pihak travel diharuskan memesan terlebih dahulu karena jeruk yang ada merupakan komoditas pertanian yang akan langsung dijual ke pengepul apabila tidak dipesan terlebih dahulu.

\section{Sumber Cinde}

Sumber Cinde merupakan mata air yang terletak berdekatan dengan Pasar Tradisional Hutan Papringan. Secara fungsi, Sumber Cinde biasanya digunakan warga untuk mencukupi kebutuhan air bersih dengan menyalurkan air melalui pipa dan selang-selang yang terhubung ke perumahan warga. Secara budaya, terdapat beberapa ritual yang dilakukan secara personal oleh masyarakat lokal untuk ngalap berkah (mencari keberkahan)

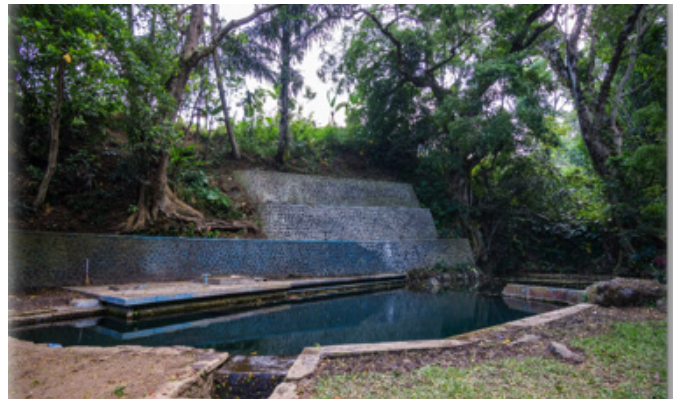

Gambar 5. Sumber Cinde di Desa Bumiaji. (Sumber: Dokumentasi Tim PKM Desa Bumiaji Prodi Pariwisata tahun 2019) melalui bertapa dan mandi di air sumber.

Untuk operasional distribusi air, Sumber Cinde dikelola oleh PDAM Kota Batu. PDAM Kota Batu bertanggung jawab terhadap aspek operasional dan perawatan dari pipa-pipa distribusi air. Di sisi lain, pemerintah desa bertanggung jawab dalam pemanfaatan lanskap dan aktivitas kunjungan wisata. Pihak Pemerintah Desa telah membangun beberapa amenitas seperti dua gubuk peristirahatan dan merencanakan untuk menginisiasi aktivitas wisata lain di lokasi ini.

\section{Bukit Teletubbies}

Bukit Teletubbies merupakan sabana berukuran kurang lebih 5 hektare dengan panorama Gunung Arjuna. Umumnya, masyarakat lokal menjadikan tempat ini sebagai lokasi untuk berekreasi secara berkelompok dengan duduk-duduk di sekitaran pintu masuk. Tidak jarang pula masyarakat lokal yang datang ke lokasi ini pada malam hari untuk melihat bintang yang terlihat jelas saat musim kemarau. 
Atas penunjukan dari pemerintah desa, Kelompok Sadar Wisata Desa Bumiaji menjadi penanggung jawab dari pengelolaan aktivitas wisata ini. Pihak Kelompok Sadar Wisata juga telah menerbitkan peraturan untuk meregulasi aktivitas wisata di Bukit Teletubbies. Terdapat rencana untuk menerapkan aturan pembayaran tiket masuk untuk menunjang kebutuhan operasional perawatan dan pengelolaan, tetapi belum dilaksanakan.

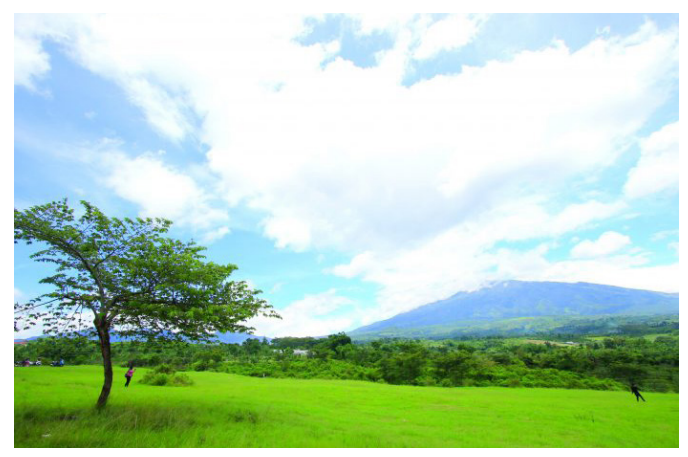

Gambar 6. Bukit Teletubbies. (Sumber: Dokumentasi Tim PKM Desa Bumiaji Prodi Pariwisata tahun 2019)

\section{Kebun Bunga Krisan}

Kebun Bunga Krisan terletak bersebelahan dengan lokasi atraksi wisata petik jambu kristal. Kebun bunga ini umumnya digunakan oleh pengunjung sebagai lokasi swafoto. Pengunjung yang datang ke lokasi ini biasanya berupa rombongan kecil, yakni sekitar dua hingga lima orang. Bunga-bunga yang ada di kebun ini biasanya akan diambil oleh pengepul untuk dijual sebagai bahan dasar karangan bunga, dengan jangkauan distribusi di sekitaran Kota Batu, Kabupaten Malang, dan beberapa kabupaten lain di sekitar

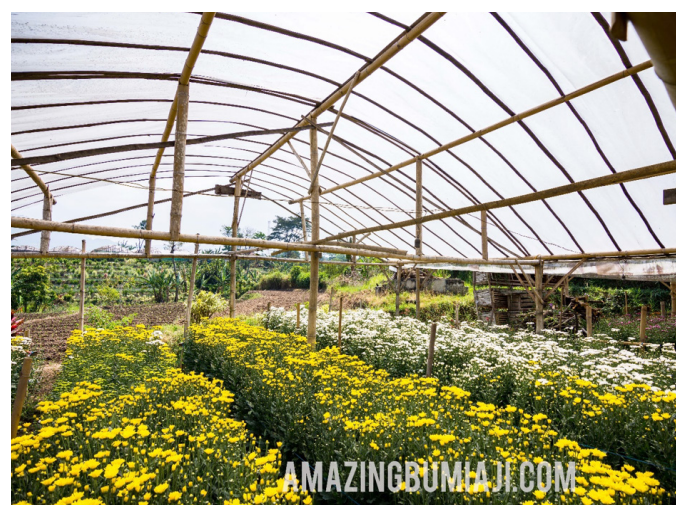

Gambar 7. Kebun Bunga Krisan. (Sumber: Dokumentasi Tim PKM Desa Bumiaji Prodi Pariwisata tahun 2019) Kabupaten Malang seperti Kabupaten Lumajang, Kabupaten Pasuruan, Kabupaten Kediri, dan Kota Surabaya.

Atraksi wisata ini dikelola secara perorangan. Belum ada tiket masuk yang dibebankan kepada pengunjung. Biaya operasional diperoleh dari hasil penjualan bunga tersebut ke distributor. Wisatawan juga dapat membeli langsung bunga di lokasi tersebut. Sampai saat ini, hanya terdapat program bantuan promosi dari pihak pemerintah desa, baik secara daring maupun luring, tanpa menerapkan sistem bagi hasil dengan pemerintah desa.

\section{Pasar Tradisional Hutan Papringan}

Pasar Tradisional Hutan Papringan merupakan atraksi wisata baru yang pendiriannya baru dimulai pada pertengahan Juni 2019. Pembangunan lokasi yang direncanakan sebagai pasar tradisional ini didanai oleh dana alokasi pengembangan pariwisata dari pemerintah Desa Bumiaji. Lokasi ini memiliki wahana permainan tradisional, kios kuliner tradisional, dan lokasi swafoto.

Pasar Tradisional Hutan Papringan dikelola oleh kelompok karang taruna Desa Bumiaji. Semula, pengelolaan Pasar Tradisional Hutan Papringan akan diserahkan kepada Kelompok Sadar Wisata, tetapi atas dasar pertimbangan pemerataan tugas pembangunan organisasi desa, pengelolaan Pasar Tradisional Hutan Papringan lalu diserahkan kepada karang taruna Desa Bumiaji. 


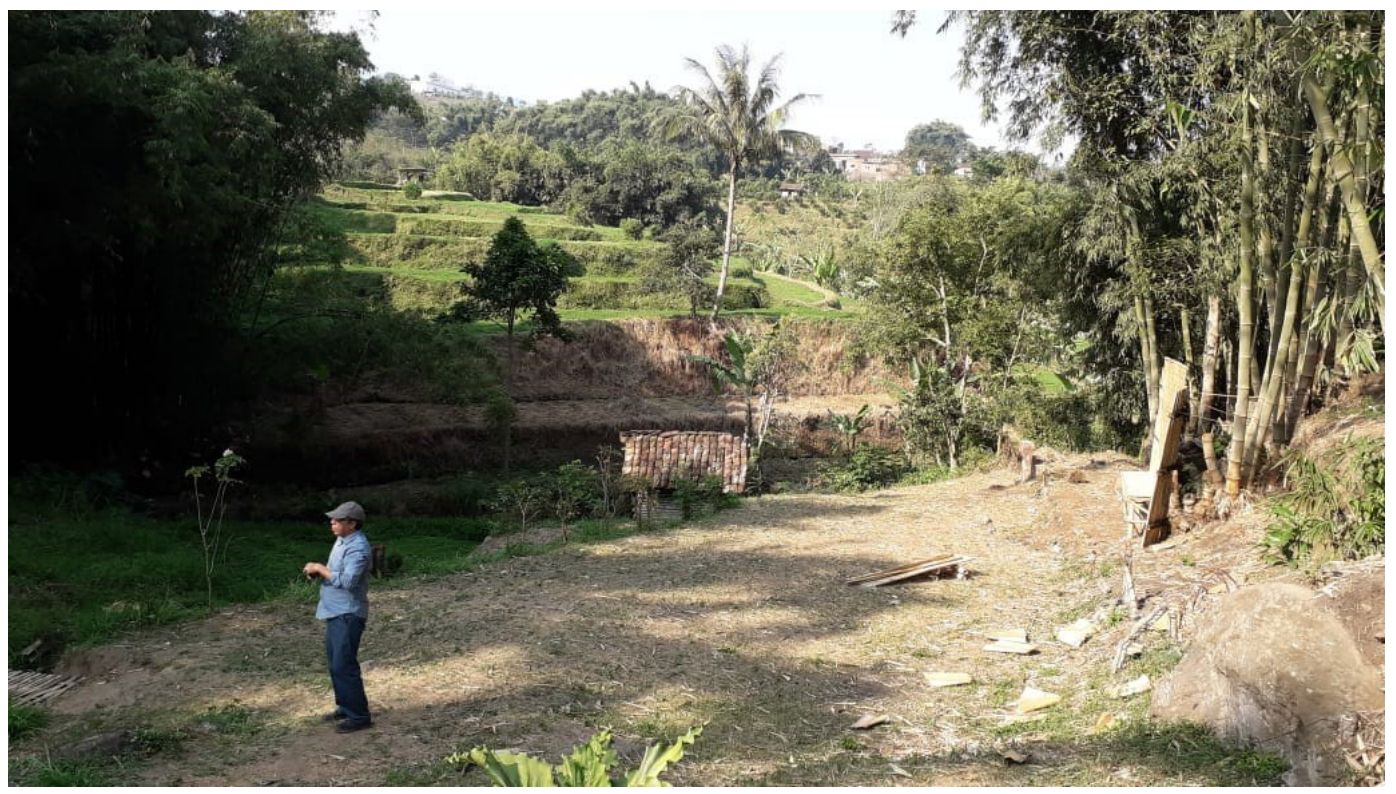

Gambar 8. Hutan Papringan (Tim PKM Desa Bumiaji). (Sumber: Dokumentasi Tim PKM Desa Bumiaji Prodi Pariwisata tahun 2019)

\section{Omah Budaya Slamet}

Omah Budaya Slamet merupakan galeri seni yang dimiliki secara personal oleh Bapak Slamet, seorang seniman Kota Batu. Di lokasi ini, terdapat koleksi-koleksi lukisan Bapak Slamet. Terdapat sebuah perpustakaan umum yang dapat diakses secara bebas oleh masyarakat lokal. Selain itu, terdapat beberapa kegiatan mingguan seperti pembelajaran cukil kayu, workshop melukis, serta pelatihan melukis di kanvas berukuran kecil, besar, dan sedang yang diadakan oleh Bapak Slamet atas pesanan

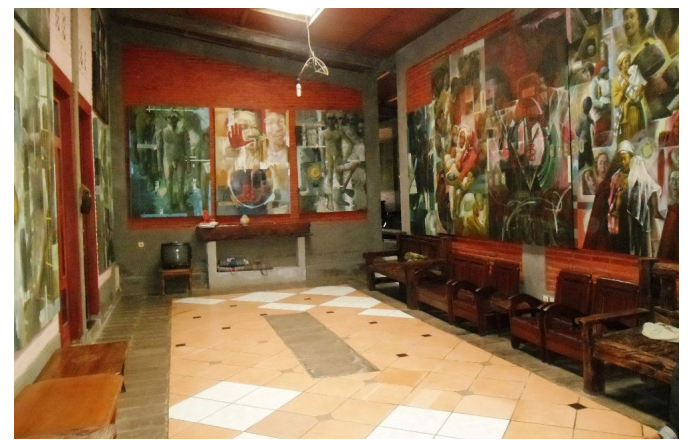

Gambar 9. Omah Budaya Slamet. (Sumber: Dokumentasi Tim PKM Desa Bumiaji Prodi Pariwisata tahun 2019) dari pengunjung.

Pengelolaan galeri seni ini sepenuhnya dikelola secara perorangan. Pihak pemerintah desa beberapa kali menjalin kerja sama dengan Bapak Slamet, terutama untuk berpartisipasi dalam kegiatan kebudayaan desa dan pendampingan mahasiswa KKN UGM. Selain itu, pihak pemerintah desa juga membantu mempromosikan kegiatan kesenian dan pelatihan yang digelar secara reguler oleh pemilik galeri.

\section{Kebun Mawar}

Kebun mawar di Desa Bumiaji ini terletak di tanah kas desa. Kebun ini terletak di dekat lokasi permukiman warga yang berdekatan dengan kebun jeruk, yang dikelola oleh masyarakat lokal. Lokasi ini belum secara aktif digunakan sebagai atraksi wisata di Desa Bumiaji. Selain itu, terdapat pemandangan Gunung Arjuna yang dapat dilihat langsung di lokasi kebun mawar. 


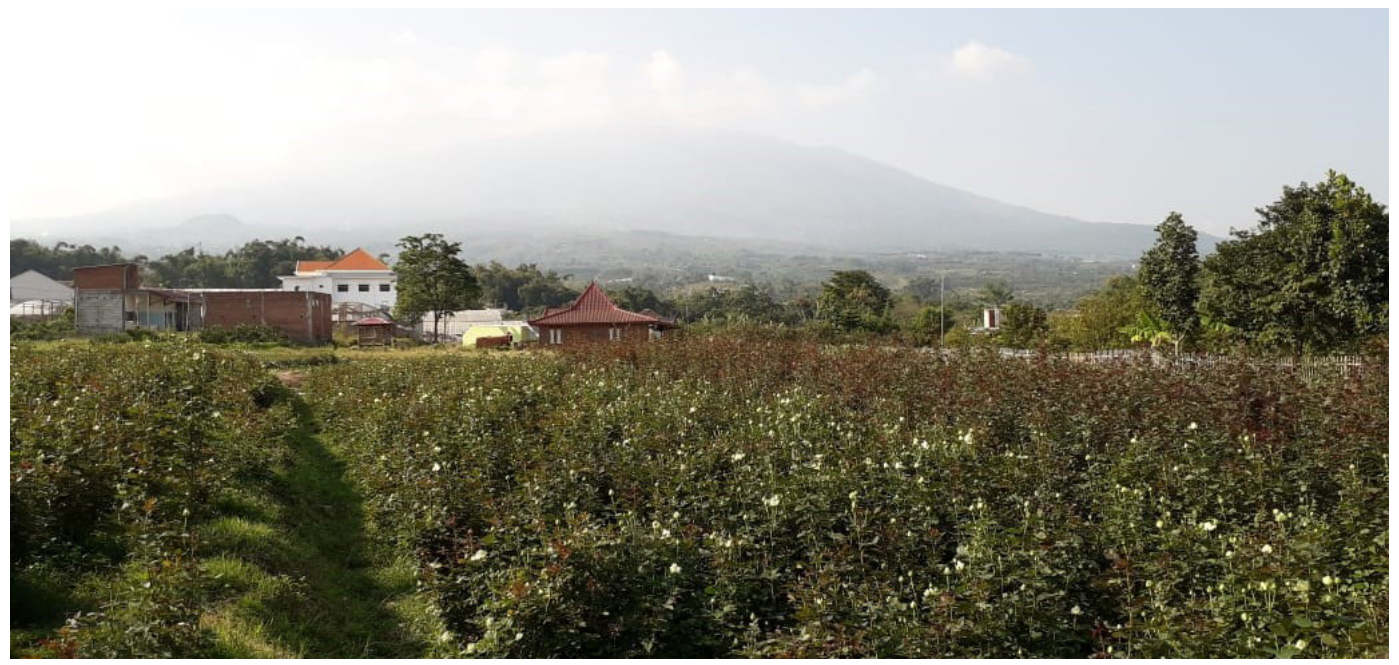

Gambar 10. Kebun Mawar. (Sumber: Dokumentasi Tim PKM Desa Bumiaji Prodi Pariwisata tahun 2019)

Pada tahap inisiasi pengembangan kebun mawar sebagai atraksi wisata ini, pihak desa menggunakan dana alokasi pengembangan pariwisata untuk pembelian bibit dan penyemaian. Lokasi ini direncanakan sebagai spot swafoto yang akan dikelola oleh pemerintah desa. Akan ada beberapa penambahan amenitas seperti gardu pandang dan gazebo di tengah lokasi kebun mawar ini.

\section{Permasalaban dan Isu Strategis dalam Pengelolaan Kepariwisataan di Desa Bumiaji}

Pada dasarnya, setiap atraksi wisata di Desa Bumiaji telah memiliki institusi/lembaga pengelola yang didaftarkan di pemerintah desa. Pihak pemerintah desa hanya menjalankan fungsi sebagai fasilitator dan pendukung program pengembangan pariwisata dengan upaya-upaya promosi. Salah satu upaya fasilitasi yang telah dilakukan adalah bekerja sama dengan konsultan swasta untuk mendapatkan arahan pengembangan aktivitas pariwisata di Desa Bumiaji. Program kerja sama tersebut umumnya menghasilkan beberapa aktivitas promosi melalui kerja sama dengan televisi nasional, media cetak lokal, dan inisiasi festival-festival desa seperti Festival Bumiaji, Festival Wirausaha, dan Festival Kebudayaan.

Terdapat beberapa atraksi wisata di Desa Bumiaji yang dikelola secara perorangan. Pendirian atraksi wisata ini umumnya berdasarkan inisiatif individu yang mengelola atraksi wisata tersebut. Setelah proses pendirian, pengelolaan sepenuhnya menjadi tanggung jawab dari pemilik atraksi wisata tersebut. Pemerintah desa, karang taruna dan Kelompok Sadar Wisata hanya terlibat dalam program-program fasilitasi seperti workshop dan pelatihan pengelolaan atraksi wisata serta workshop pemanduan dan penyediaan lapak ketika ada festival kebudayaan di Desa Bumiaji guna membantu promosi atraksi wisata tersbeut.

Pada dasarnya, secara kolektif, Kelompok Sadar Wisata di Desa Bumiaji berfungsi sebagai pengelola beberapa atraksi wisata saja dan berada di bawah instruksi dari Pemerintah Desa. Selain Kelompok Sadar Wisata, karang taruna merupakan organisasi di bawah pemerintah desa yang bertugas mengelola Pasar Tradisional Hutan Papringan. Pemerintah 
Desa Bumiaji berperan sebagai inisiator dan fasilitator pembangunan pariwisata. Proses koordinasi dilakukan oleh Pemerintah Desa dengan rutin menyelenggarakan forum diskusi, pelatihan usaha jasa pariwisata, dan pelatihan kepemanduan. Upaya-upaya tersebut dilakukan melalui kerja sama dengan beragram mitra seperti Metro TV, TV One, konsultan pariwisata, dan pemerintah kecamatan.

Upaya pengembangan pariwisata yang telah dilakukan di Desa Bumiaji tidak terpusat pada satu kelembagaan khusus. Hal ini menyebabkan program-program yang dijalankan bertumpang tindih. Sebagai contoh, beberapa atraksi wisata baru didirikan oleh pemerintah desa pada awal tahun 2019. Pengelolaan atraksi wisata tersebut diserahkan kepada Kelompok Sadar Wisata dan karang taruna Desa Bumiaji. Akan tetapi, kurangnya koordinasi dengan pihak pemerintah Kecamatan Bumiaji menyebabkan dua atraksi wisata tersebut tidak masuk dalam video promosi yang dibuat oleh pemerintah kecamatan.

Sebaliknya, pihak kecamatan telah memutuskan untuk bekerja sama dengan konsultan pariwisata lokal dalam upaya pengembangan pariwisata Desa Bumiaji. Kerja sama tersebut merumuskan program-program strategis pengembangan pariwisata, seperti penyelenggaraan event kebudayaan dan mendatangkan kunjungan wisata rombongan pada 2018. Dalam pelaksanaannya, aktivitas pariwisata justru dikelola oleh event organizer yang membuat pemerintah desa dan masyarakat lokal kebingungan.

Selain itu, tidak adanya peraturan terkait pengelolaan pariwisata dan perizinan pelaksanaan aktivitas wisata membuat inisiasi pendirian aktivitas wisata berjalan tidak terorganisasi. Hal tersebut direpresentasikan oleh tumpang tindihnya agenda pembangunan pariwisata di Desa Bumiaji. Akibatnya, keuntungan ekonomi dari adanya aktivitas pengembangan pariwisata tidak dapat diserap secara maksimal oleh pemerintah desa dan masyarakat lokal.

\section{Diskusi dan Rekomendasi Struktur Kelembagaan dalam Pengelolaan Pariwisata Desa di Desa Bumiaji}

Berdasarkan permasalahan dan isu strategis yang ada dalam pengelolaan pariwisata di Desa Bumiaji, diusulkan sebuah model kelembagaan yang integratif dan dapat diadaptasi sebagai kerangka pengelolaan aktivitas wisata di Desa Bumiaji. Secara umum, skema yang ditawarkan didasarkan pada skema organisasi manajemen destinasi (Destination Management Organisation) (Adeyinka-Ojo et al., 2014). Skema tersebut membagi tugas pembangunan utama menjadi dua, yaitu manajemen atraksi wisata dan pemasaran atraksi wisata. Dalam operasionalisasi pelaksanaannya, kerangka institusi pengelolaan yang diajukan menekankan adanya suatu pemangku kepentingan yang secara legal mengorganisasi aktivitas pengembangan pariwisata di Desa Bumiaji.

Berdasarkan temuan, organisasi yang diusulkan untuk menjadi pemangku kepentingan utama adalah Kelompok Sadar Wisata. Dalam unsur kelembagaan Kelompok Sadar Wisata diperlukan perwakilan dari pemangku kepentingan lain yang menjabat sebagai pembina, yaitu perwakilan dari pemerintah Desa Bumiaji, pemerintah Kecamatan Bumiaji, Dinas Pariwisata Kota Batu, dan Dinas Pariwisata Kabupaten Malang. Berdasarkan analisis, skema kelembagaan yang diusulkan ditunjukkan pada Gambar 3. 


\begin{tabular}{|c|c|c|}
\hline $\begin{array}{l}\text { - Manajemen Destinasi } \\
\text { (Dinas Pariwisata Kota } \\
\text { Batu, Pemerintah Desa } \\
\text { Bumiaji dan Kelompok } \\
\text { Sadar Wisata) } \\
\text { - Bendahara } \\
\text { - Divisi Pengelolaan dan } \\
\text { Pengembangan SDM } \\
\text { - Divisi Keamanan dan } \\
\text { Ketertiban Lingkungan } \\
\text { - Divisi Hubungan } \\
\text { Masyarakat dan } \\
\text { Komunikasi }\end{array}$ & $\begin{array}{l}\text { Pembina: } \\
\text { - } \quad \text { Dinas Pariwisata } \\
\text { Kabupaten Malang } \\
\text { - } \quad \text { Dinas Pariwisata Kota Batu } \\
\text { - } \quad \text { Pemerintah Desa Bumiaji } \\
\text { - } \quad \text { Pemerintah Kecamatan } \\
\text { Bumiaji } \\
\text { Pengelola: } \\
\text { - Kelompok Sadar Wisata } \\
\text { Desa Bumiaji }\end{array}$ & $\begin{array}{l}\text { Manajemen Marketing } \\
\text { (Dinas Pariwisata } \\
\text { Kabupaten Malang, } \\
\text { Pemerintah Kecamatan } \\
\text { Bumiaji, Karang Taruna } \\
\text { Desa Bumiaji dan } \\
\text { Kelompok Sadar Wisata } \\
\text { Desa Bumiaji) } \\
\text { - Divisi Promosi dan } \\
\text { Pemasaran } \\
\text { Divisi Litbang } \\
\text { Divisi Pengelola Aset } \\
\text { dan Atraksi Wisata } \\
\text { Divisi Pelayanan } \\
\text { Konsumen } \\
\text { Divisi Kreatif }\end{array}$ \\
\hline
\end{tabular}

Gambar 11. Usulan Skema Kelembagaan Pengelola Pariwisata Desa di Desa Bumiaji (Sumber: Hasil analisis oleh Tim PKM Desa Bumiaji Prodi Pariwisata 2019)

Dalam skema yang diusulkan, Kelompok Sadar Wisata menjadi lembaga formal yang memiliki kewenangan sepenuhnya terhadap kebijakan dan upaya-upaya pengembangan aktivitas pariwisata. Akan tetapi, operasional Kelompok Sadar Wisata sepenuhnya berada dalam pengawasan pembina, yaitu Dinas Pariwisata Kabupaten Malang, Dinas Pariwisata Kota Batu, pemerintah Desa Bumiaji, dan pemerintah Kecamatan Bumiaji. Selain itu, dalam pelaksanaan pengelolaan kepariwisataan di Desa Bumiaji, masing-masing pembina memiliki tanggung jawab yang disesuaikan dengan minat dan ketertarikan serta upaya-upaya pengembangan pariwisata eksisting.

Di tabel sebelah kiri, operasionalisasi manajemen destinasi merupakan tanggung jawab Kelompok Sadar Wisata dengan sokongan Dinas Pariwisata Kota Batu dan pemerintah Desa Bumiaji. Selama ini, pemerintah Desa Bumiaji dan Dinas Pariwisata Kota Batu cenderung menginisiasi program yang ada kaitannya dengan pelatihan sumber daya manusia, sosialisasi sadar wisata ke masyarakat lokal, dan distribusi dana bantuan pengelolaan pariwisata. Berdasarkan hal tersebut, pihak pemerintah Desa Bumiaji dan Dinas Pariwisata Kota Batu dapat berkolaborasi untuk membina divisi-divisi dalam kelompok sadar wisata, yaitu divisi pengelolaan SDM yang bertanggung jawab dalam memberi pelatihan kepariwisataan serta regenerasi organisasi; divisi keamanan dan ketertiban lingkungan yang bertanggung jawab atas keamanan kawasan untuk mendukung aktivitas pariwisata dan pengelolaan parkir; divisi hubungan masyarakat yang bertugas untuk mengoordinasikan setiap aktivitas wisata kepada masyarakat dan penampungan aspirasi masyarakat lokal; dan bendahara yang mengelola distribusi keuangan internal yang diperoleh dari aktivitas wisata.

Tabel di sebelah kanan menjelaskan skema manajemen pemasaran yang dikelola oleh Kelompok Sadar Wisata Desa Bumiaji dengan pembinaan dari pihak Dinas Pariwisata Kabupaten Malang, pemerintah Kecamatan Bumiaji, dan karang taruna Desa Bumiaji. Selama ini, program pemasaran yang telah dilakukan, seperti pembuatan video 
pemasaran, pembuatan website pariwisata Desa Bumiaji, dan penyelenggaraan festival kebudayaan untuk mempromosikan atraksi wisata di Desa Bumiaji, utamanya diinisiasi oleh pemerintah kecamatan. Pemerintah kecamatan juga melakukan koordinasi langsung dengan pihak Dinas Pariwisata Kabupaten Malang untuk mengonsultasikan pelaksanaan festival kebudayaan. Secara terperinci, terdapat beberapa divisi dalam manajemen pemasaran, yaitu divisi promosi dan pemasaran yang bertanggung jawab atas upaya promosi dan pemasaran kepariwisataan; divisi penelitian dan pengembangan (litbang) yang bertugas untuk melakukan update data dan menentukan strategi branding dan positioning dalam pemasaran; divisi pengelola aset dan atraksi wisata yang bertanggung jawab terhadap upaya perawatan dan pengelolaan aset wisata; divisi pelayanan konsumen untuk merespons keluhan wisatawan dan mengatur jadwal kunjungan wisatawan; dan divisi kreatif yang merumuskan konsep-konsep pengembangan atraksi wisata baru. Kelima divisi ini bekerja secara simultan dengan koordinasi yang rutin melalui adanya rapat koordinasi dan evaluasi bulanan yang diinisiasi oleh pembina.

\section{Penutup}

Program pengabdian masyarakat di Desa Bumiaji, Kota Batu, Kabupaten Malang, Jawa Timur yang dilaksanakan oleh Prodi Pariwisata FIB UGM ini menjadi upaya para dosen Prodi Parwisata untuk berkontribusi dalam pembangunan kepariwisataan masyarakat desa melalui penerapan dan aplikasi kepakarannya. Program pengabdian masyarakat ini menitikberatkan pada aspek restrukturisasi kelembagaan yang mengelola pengembangan pariwisata di Desa Bumiaji. Program pengabdian masyarakat ini melibatkan partisipasi masyarakat sejak awal hingga akhir kegiatan dengan mengacu pada aspek akademik dan berlandaskan teori-teori kolaborasi pemangku kepentingan dalam pengelolaan aktivitas wisata desa serta paradigma dalam studi ilmu sosial dan humaniora. Di tahapan pertama, program pengabdian masyarakat ini hanya menghasilkan usulan skema kelembagaan dalam pengelolaan pariwisata desa di Desa Bumiaji, yang dapat diadaptasi sebagai kerangka pendirian lembaga pengelola yang integratif dan akomodatif bagi kepentingan partisipasi masyarakat. Program selanjutnya diharapkan tidak hanya fokus kepada aspek pengabdian masyarakat, tetapi terintegrasi juga dengan program penelitian sosial budaya, khususnya di bidang studi pariwisata seperti ekowisata, pariwisata berbasis masyarakat, dan perencanaan pariwisata. Hal tersebut diharapkan dapat mendukung dan memunculkan konsep, teori, atau model baru terkait dengan studi pariwisata yang dihasilkan melalui program pengabdian masyarakat. Selain itu, perumusan konsep, teori, atau model baru tersebut diharapkan dapat digunakan untuk mengembangkan program-program pengabdian masyarakat selanjutnya.

\section{Catatan}

Artikel ini disusun atas bantuan dan kerja sama dari tim pengabdian kepada masyarakat Program Studi Pariwisata FIB UGM, khususnya Dr. Tular Sudarmadi, M.A. dan Dr. Wiwik Sushartami, M.A. sebagai fasilitator diskusi kelompok; Yulita Kusuma Sari sebagai koordinator teknis pelaksanaan focus group discussion; Fahmi Prihantoro, S.S., S.H., M.A. sebagai moderator focus group discussion; Priscila Meyda Bening dan Alanis Angelita 
sebagai pengumpul data, observatori lapangan, dan penanggung jawab administrasi; dan Hafidz Irshadin sebagai pengumpul data serta pembuat video dokumenter pengabdian kepada masyarakat Program Studi Pariwisata FIB UGM. Penulis menyampaikan terima kasih sepenuhnya atas kerja sama dan bantuan selama pelaksanaan pengabdian kepada masyarakat di Desa Bumiaji, Kota Batu, Kabupaten Malang, Jawa Timur.

\section{Daftar Pustaka}

Adeyinka-Ojo, S.F., C. Khoo-Lattimore, dan V. Nair. (2014). "A Framework For Rural Tourism Destination Management And Marketing Organisations" dalam ProcediaSocial and Behavioral Sciences, Vol. 144, hlm. 151-163.

Atorough, P. dan A. Martin. (2012). "The Politics Of Destination Marketing: Assessing Stakeholder Interaction Choice Orientations Toward A DMO Formation, Using The Thomas-Kilmann Conflict Mode Instrument" dalam Journal of Place Management and Development, Vol. 5, No. 1, hlm. 35-55.

Byrd, E.T. (2007). "Stakeholders In Sustainable Tourism Development And Their Roles: Applying Stakeholder Theory To Sustainable Tourism Development" dalam Tourism Review, Vol. 62, No. 2, hlm. 6-13.

Forstner, K. (2004). "Community Ventures And Access To Markets: The Role Of Intermediaries In Marketing Rural Tourism Products" dalam Development Policy Review, Vol. 22, No. 5, hlm. 497-514.

Gascón, J. (2013). "The Limitations Of Community-Based Tourism As An Instrument Of Development Cooperation: The Value Of The Social Vocation Of The Territory Concept" dalam Journal of Sustainable Tourism, Vol. 21, No. 5, hlm. 716-731.

Jamal, T.B. dan D. Getz. (1995). "Collaboration Theory And Community Tourism Planning” dalam Annals of Tourism Research, Vol. 22, No. 1, hlm. 186-204.

Lane, B. (1994). "Sustainable Rural Tourism Strategies: A Tool For Development And Conservation” dalam Journal of Sustainable Tourism, Vol. 2, No. 1-2, hlm. 102-111.

Manyara, G. dan E. Jones. (2007). "Community-Based Tourism Enterprises Development In Kenya: An Exploration Of Their Potential As Avenues Of Poverty Reduction" dalam Journal of Sustainable Tourism, Vol. 15, No. 6, hlm. 628-644.

Pemerintah Kabupaten Malang. (2015). Peraturan Daerah Kabupaten Malang Nomor 1 Tahun 2015 tentang Rencana Pembangunan Pariwisata Daerah.

Ruiz-Ballesteros, E. dan R. Cáceres-Feria. (2016). "Community-Building And Amenity Migration In Community-Based Tourism Development: An Approach From Southwest Spain" dalam Tourism Management, Vol. 54, hlm. 513-523.

Salazar, N.B. (2012). "Community-Based Cultural Tourism: Issues, Threats And Opportunities" dalam Journal of Sustainable Tourism, Vol. 20, No. 1, hlm. 9-22.

Sebele, L. S. (2010). "Community-Based Tourism Ventures, Benefits And Challenges: Khama Rhino Sanctuary Trust, Central District, Botswana" dalam Tourism Management, Vol. 31, No. 1, hlm. 136-146.

Sharpley, R. (2002). "Rural Tourism And The Challenge Of Tourism Diversification: The Case Of Cyprus" dalam Tourism Management, Vol. 23, No. 3, hlm. 233-244.

Suansri, P. (2003). Community Based Tourism Handbook. Bangkok: Responsible Ecological Social Tour-REST.

Zhao, W., J.B. Ritchie, dan C.M. Echtner. (2011). "Social Capital And Tourism Entrepreneurship" dalam Annals of Tourism Research, Vol. 38, No. 4, 1570-1593. 